\title{
A IMPARCIALIDADE DO JUIZ DAS GARANTIAS SOB A ÓTICA DE ARISTÓTELES
}

\author{
Guilherme Amorim Campos da Silva ${ }^{1}$ \\ Enedino Januário de Miranda e Silva ${ }^{2}$
}

\section{RESUMO}

O magistrado justo equidistante manifesta-se no âmbito interno do processo livre dos interesses conflituosos sobretudo no freio estatal do jus puniendi. Logo, a função jurisdicional do juiz caracteriza-se pela imparcialidade nos processos, referenciando-se, por exemplo, no conceito de justiça corretiva e de equidade de Aristóteles. Neste diapasão jurídico, o artigo discorre sobre a sistemática filosófica da justiça em Aristóteles, recepcionando o conceito do juiz das garantias inserido na lei 13.964/2019, e sua aplicabilidade.

Palavras-chave: Platão. Aristóteles. Juiz das Garantias. Justiça. Imparcialidade.

\section{THE IMPARTIALITY OF THE JUDGE OF GUARANTEES FROM THE VIEWPOINT OF ARISTOTLE}

\begin{abstract}
The equidistant just magistrate manifests itself within the internal scope of the process free of conflicting interests, above all, in the state brake of jus puniendi. Therefore, the jurisdictional function of the judge is characterized by impartiality in the proceedings referring, for example, to Aristotle's concept of corrective justice and equity. In this legal tuning, the article discusses the philosophical systematics of justice in Aristotle, accepting the concept of the judge of guarantees inserted in Law 13.964/2019 and its applicability.
\end{abstract}

Keywords: Plato. Aristotle. Warranty Judge. Justice. Impartiality.

\section{INTRODUÇÃO}

Ao estudar Aristóteles, observa-se suas facetas em diversas áreas das ciências, dedicando-se a vários ramos do conhecimento, como a Política, Ética, Biologia, entre outros. Dentre todos os filósofos da Antiguidade, atribui-se a Aristóteles um maior desenvolvimento de temas direcionados à Filosofia do Direito. Foi Aristóteles quem escrutinou as primeiras

\footnotetext{
1 Doutor e Mestre em Direito pela PUC, é professor permanente do programa de Mestrado e Doutorado em Direito da Universidade Nove de Julho. Membro fundador e diretor do Instituto Brasileiro de Estudos Constitucionais. Endereço postal: Rua Vergueiro - até 1289 - lado ímpar, Liberdade, 01504001 - São Paulo, SP Brasil. E-mail: guilherme.amorim@uni9.pro.br

${ }^{2}$ Mestre e Graduado em Direito pela Universidade Nove de Julho, com especialização em Gestão de Negócios pela USP. Especialista na área de Relação de Consumo. Endereço postal: Avenida Nicolau Jacinto, 685 Torre 4 Sala 82 - São Nicolau - 03687010 - São Paulo, SP - Brasil. E-mail: enedino.januario@gmail.com.
} 
lições de Justiça dentro de uma perspectiva essencialmente jurídica, considerando as ideias de justiça e equidade como nascedouros inspiracionais do Direito e da Lei.

As primeiras concepções de justiça, exemplificadas no livro V da Ética a Nicômaco de Aristóteles, a compreendem como uma virtude, diferenciando-se das demais devido a superioridade na aplicação da excelência moral em relação aos indivíduos e não em relação a si mesmo, ou seja, visa o "bem do outro". Assim, a justiça (dikayosyne) é a "disposição da alma que graças à qual elas dispõem a fazer o que é justo, a agir justamente e a desejar o que é justo" O inverso seria a injustiça (aidikía), a "disposição da alma de graças à qual elas agem injustamente e desejam o que é injusto" (ARISTÓTELES, 1996, p. 193). Logo, a justiça é a excelência moral perfeita e o justo é aquele que respeita a lei e é correto. O injusto é o ilegal (CHALITA, 2017).

De tal sorte, é possível determinar mais uma garantia institucional e de justiça com a introdução do juiz das garantias inserido no Pacote Anticrime pela lei 13.964/2019 e sancionado pelo presidente Jair Bolsonaro no dia 24 de dezembro de 2019. O novo modelo estabelece a previsão de atuação de 2 juízes - o juiz de instrução, responsável pela Sentença Absolvitória ou Condenatória, e o juiz das garantias, responsável pelas decisões necessárias na fase de investigação. Existindo a divisão da competência funcional na etapa pré-processual e de admissibilidade da acusação, pode representar verdadeiramente enorme e evidente avanço no processo penal brasileiro, além de garantir maior isenção no processo criminal.

É oportuno afirmar que a imparcialidade - de participantes do sistema de justiça pode ser real e preocupante visto que o resultado deste processo poderá ser enviesado em razão das suas próprias experiências e embutes com longa série de concepções prévias, ou seja, visualiza-se uma quimera na persecução penal e nos demais membros integrantes dos institutos criminais. O juiz das garantias impediria a adoção de qualquer tipo de prática em desacordo com a ordem jurídico-constitucional (D’URSO, 2019), e ao longo do tempo poderá aperfeiçoar e refinar a cultura da imparcialidade na pauta deontológica do processo criminal, na pauta de todos os magistrados e, por fim, em todo o Direito normativo brasileiro.

\section{PRELÚDIO}




\subsection{PLATÃO}

Platão foi um filósofo da Grécia Antiga com inquestionável contribuição aos alicerces da filosofia natural, da filosofia ocidental e da ciência. Dentre os notórios destaques, destaca-se a fundação da Academia - em Atenas - sendo também autor de diversos diálogos filosóficos e da obra A República. Seu verdadeiro nome é Arístocles e o apelido Platão advém da constituição robusta, porte físico vigoroso e ombros muito largos.

O convívio, desde criança, com personalidades políticas advindas do relacionamento da família tradicional e de sua mãe - filha do renomado legislador Sólon ${ }^{3}$, permitiram a Platão conhecer com profundidade os bastidores da política em Atenas. Fato marcante para Platão na adolescência foi conhecer Sócrates que, mais tarde, tornou-se seu mestre.

Episódio curioso é o aparecimento de Platão na vida de seu mestre Sócrates, primeiramente sob a forma de sonho. Após Sócrates sonhar com um cisne e tendo Platão se apresentado no dia seguinte a ele para ouvir as palestras do já então famoso filósofo, Sócrates concluiu que o cisne de seu sonho era seu novo discípulo. $\mathrm{O}$ cisne representava para os gregos um atributo simbólico do deus Apolo, um sinal do caráter apolíneo de seu discípulo Platão.

Ser apolíneo significava ser amante da ordem, da beleza tranquila e da razão paciente e calculista - imagem que por muito tempo foi conferida a todo o Classicismo e a Arte Clássica Grega, em particular, em oposição ao caráter dionisíaco do deus Dioniso, deus da embriaguez, como também ao caráter barroco das artes, que é, no entanto, tão grego e clássico quanto o caráter apolíneo (WATANABE, 2006, p. 34).

Por difundir ideias contrárias à religião tradicional, Sócrates é condenado e sentenciado à morte, algo impensável por Platão, visto a injustiça descabida ao mestre após toda contribuição relevante na Pólis ${ }^{4}$, seu senso de justiça e por ser um dos homens mais sábios à época. É neste momento que Platão questiona se a Democracia é, de fato, a melhor forma de governo, de maneira que se lança no êxodo, em conjunto com outros colegas, para aprofundamento dos estudos e encontrar respostas às suas dúvidas.

\footnotetext{
${ }^{3}$ Estadista, legislador e poeta grego antigo considerado pelos gregos como um dos sete sábios da Grécia antiga. ${ }^{4}$ É a denominação para cidade-estado. Constituída por um aglomerado urbano, abrangia toda a vida pública de um pequeno território e geralmente encontrava-se protegida por uma fortaleza. Compreendia a totalidade dos cidadãos, exceto os escravos, metecos e membros de populações subjugadas e distinguia-se de outras cidades pelo nome dos seus habitantes.
} 
Na peregrinação estudantil, convive com Arquitas de Tarento ${ }^{5}$, momento no qual tem a oportunidade de conhecer formas de governar. Nestas capturas de exemplo vivaz, Platão concebe as primeiras ideias que, ao logo dos anos, resultarão na obra que denominada $A$ República. Tal obra é composta por 10 livros e traz aspectos interessantes como a organização da família na cidade ideal e o papel da mulher na vida pública ${ }^{6}$.

Atentando-se ao tema justiça, na obra mencionada, esta não é tratada de um ponto de vista jurídico, mas sim ontológico, visto que as ideias de ética e virtude se conectam diretamente à ideia de conhecimento como algo necessário (BITTAR; ALMEIDA, 2015, p. 133).

Nos diálogos platônicos, a cidade justa deve ser governada e administrada pelos filósofos e pelos homens da ciência, haja vista sua sabedoria em relação às demais classes da cidade, que permitiria cumprir, naturalmente, sua função para o bem da Pólis. Logo, seria injusto um artesão ser governante, devido sua função de produzir bens e serviços para o bem da sociedade, em razão de sua temperança, de tal modo que os auxiliares policiam e defendem a Pólis justamente por serem mais corajosos que os artesãos.

Deste entendimento, nasce o primeiro conceito de justiça platônica, cuja definição se formularia como ter cada um o que é seu e fazer aquilo para o qual é mais apto. Platão aprofunda os estudos de justiça, desta vez, levando em consideração a tripartição da alma em racional (logos), o impulso (thimós) e o apetite (epitimia), sendo necessária a harmonização para haver justiça. Como conclusão, a justiça é um estatuto abrangente, materializada com o equilíbrio harmonioso das quatro virtudes cardeais advindas da tripartição da alma e as virtudes correspondentes dos cidadãos da Pólis, que são: a sabedoria, a coragem, a moderação e a justiça; esta última, a virtude mestra que ordenará todas as demais virtudes. Aristóteles, discípulo de Platão, analisa o conceito de justiça aprofundando-se e atribuindo virtudes adicionais aos ensinamentos do mestre.

\subsection{ARISTÓTELES}

\footnotetext{
${ }^{5}$ Filósofo, cientista, matemático e astrônomo grego, considerado o mais ilustre dos matemáticos pitagóricos.

${ }^{6}$ Essa igualdade entre homens e mulheres, defendida por Platão, efetivou-se no Brasil em 1988 com a Constituição Federal, que no inciso I do artigo $5^{\circ}$ dispõe sobre o princípio da isonomia, um dos direitos fundamentais.
} 
Aristóteles nasce em 384 a.C. na cidade grega de Estagira (CHALITA, 2017). Filho de um médico da família real macedônica, mudou-se para Atenas aos dezessete anos de idade e frequentou a Academia Platônica durante 20 anos, tornando-se o discípulo mais prestigiado de Platão. Com a morte do mestre, Aristóteles não assume a Academia - por ser meteco ${ }^{7}$ - e a sucessão se dá por Espeusipo, sobrinho e discípulo de Platão. Assim, Aristóteles deixa a Academia mudando-se para Assos, na Ásia Menor.

Em 343 a.C., Filipe II convida Aristóteles para ser preceptor de seu filho, Alexandre, à época, com aproximadamente 13 anos de idade e que, mais tarde, ficou conhecido como Alexandre Magno (CHALITA, 2017). Com a morte de Filipe, Alexandre assume o trono da Macedônia e inicia sua expansão ao Oriente. Em 335 a.C., Aristóteles retorna à Atenas, e agastado por não ter assumido a Academia de Platão, decide fundar uma escola concorrente, próxima a um templo dedicado a Apolo Liceano, a sudoeste de Atenas, em um velho ginásio. Com a ajuda de Alexandre, o Grande, Aristóteles compra o imóvel e inicia a construção de sua universidade, chamada de Liceu (NEVES, 2012). Neste retorno a Atenas, ocorre a morte de esposa Pítias e, por isso, passa a viver com Herpilis. Deste matrimônio, nasce o filho chamado Nicômaco (CHALITA, 2017).

No Liceu, Aristóteles ministrava suas aulas caminhando pela escola, ensinando ao ar livre. Este hábito ficou conhecido como peripatético, ou seja, o que caminha. Aristóteles passeava com os seus alunos ao longo do perípatos, e com eles discutia as questões filosóficas mais profundas. O método didático de Aristóteles consistia em caminhar pelos ambientes (experiência empírica) buscando desenvolver nos alunos a observação, a comparação e a percepção do mundo a sua volta, trazendo reflexões de cunho prático. No período vespertino, dedicava-se a expor assuntos de menor dificuldade para uma audiência mais vasta de integrantes da Pólis. É de se observar que no Liceu havia vários campos de estudos, cujo grande expoente era o estudo das ciências naturais, em especial, a Biologia. Alexandre, o Grande, colhia exemplares da fauna e da flora em suas expedições e enviava a Aristóteles para integrar e enriquecer o acervo do Liceu.

Aristóteles determinava que os alunos realizassem pesquisas de forma abrangente, permeando os assuntos mais variados e de interesse do próprio filósofo, como a Botânica, Biologia, Lógica, Música, Matemática, Astronomia, Medicina, Cosmologia, Física, História da Filosofia, Metafísica, Psicologia, Ética, Teologia, Retórica, História política, do governo e

\footnotetext{
${ }^{7}$ Estrangeiro que possuía permissão para residir em Atenas.
} 
da teoria política, e as Artes. Os alunos do Liceu coletaram informações em todas essas áreas e, assim, de acordo com alguns relatos antigos, criou-se a primeira grande biblioteca da Antiguidade (STANFORD ENCYCLOPEDIA OF PHILOSOPHY, 2008).

Com a morte de Alexandre em 323 a.C., surge uma forte e crescente reação antimacedônica em Atenas. Aristóteles, com estreito vínculo com Alexandre, nomeou seu aluno Antípatro como chefe executivo do Liceu em 322 a.C. e, fugindo de Atenas, se dirige para a cidade de Cálcis, lar de sua mãe. O exílio forçado se dá pela própria explicação de Aristóteles: "Eu não vou permitir que os atenienses pequem duas vezes contra a filosofia" (MORRIS, 2002, p. 5). Uma clara referência ao julgamento outrora de Sócrates em Atenas. Aristóteles morre, naquele ano, de causas naturais em Cálcis, na ilha Eubeia.

Vasto foi o campo de atuação que Aristóteles percorreu à frente do Liceu, dedicandose a diversos ramos do conhecimento, tornando-se pioneiro, em relação aos filósofos da Antiguidade, no desenvolvimento de temas ligados à Filosofia do Direito, haja vista que por meio de seus estudos foi possível visualizar uma perspectiva puramente jurídica, considerando as ideias de equidade e de justiça como fontes inspiracionais da Lei e do Direito. Assim, o homem é um animal político (CHALITA, 2017), pois é levado à vida política por sua própria natureza na cidade-estado, não podendo desassociá-los.

Neste contexto, a Pólis regula a vida dos seus habitantes por meio de premissas como a Lei e a Justiça. Aristóteles classifica a Justiça como a excelência das virtudes e, fundamentalmente, destinou diversas observações ao tema. Em sua obra Ética a Nicômaco, no livro V, dedicou atenção aos problemas éticos do homem, sobre os quais realizar-se-á o aprofundamento do tema, observando se há justiça com a introdução do juiz das garantias no ordenamento jurídico brasileiro.

\section{ACEPÇÕES DE JUSTIÇA}

\subsection{A JUSTIÇA UNIVERSAL E JUSTIÇA PARTICULAR}

Aristóteles é o primeiro a propor uma teoria sistemática da justiça, diferentemente da visão de Platão. Aristóteles abre o tema conceituando o termo justiça ao explicar o potencial universal e particular. Destarte, o caráter de justiça universal é a forma de justiça na qual a virtude está inserida no todo, compreendendo todas as virtudes, constituindo-se como a 
virtude completa e perfeita, que ganha materialidade na cidade por meio das leis positivas. A justiça aristotélica não é idealizada - como pensava Platão - mas sim uma virtude adquirida com o exercício e com o hábito. Aristóteles explica que:

\begin{abstract}
A justiça é a forma perfeita de excelência moral porque ela é a prática efetiva da excelência moral perfeita. Ela é perfeita porque as pessoas que possuem o sentimento de justiça podem praticá-la não somente a si mesmas como também em relação ao próximo (ARISTÓTELES, 1996, p. 195).
\end{abstract}

Assim, o filósofo continua afirmando que a justiça é algum tipo de "disposição da alma" que se caracteriza em fazer o que é justo, a agir justamente e a desejar o que é justo. No inverso, na injustiça, o indivíduo está disposto a agir injustamente e desejar aquilo que é injusto. Tem-se que a ação justa é reconhecida pelo seu contrário, ou seja, pela ação injusta, pois "muitas das vezes se reconhece uma disposição da alma graças a outra contrária, e muitas vezes as disposições são idênticas por via das pessoas nas quais elas se manifestam" (ARISTÓTELES, 1996, p. 193).

Isto significa que a justiça será uma virtude ou excelência, refletindo atitudes do bem, as quais se fundam no próprio caráter do ser humano. Logo, o homem justo deve respeitar a igualdade e estar dentro da legalidade (AQUINO, 1993) ${ }^{8}$.

Classificadas as diferenças, prossegue o filósofo demostrando haver duas modalidades de justiça inseridas na justiça particular: Justiça Distributiva e a Justiça Corretiva, como será visto a seguir.

\title{
2.2 A JUSTIÇA DISTRIBUTIVA
}

Partindo do entendimento que a justiça corresponde plenamente a excelência moral, esta deve apresentar-se em meios de ações de prudência e moderação objetivando o meiotermo. Aristóteles determina que o meio-termo é o igual, pois em cada tipo de ação em que existe um "mais" e um "menos", existe também um "igual". Assim, nesta linha de pensamento, a justiça distributiva revela-se como uma espécie de justiça observando a

\footnotetext{
${ }^{8}$ Tomás de Aquino explica: "o homem justo é tomado de dois modos: primeiramente como uma pessoa obediente às leis, isto é, como aquele que observa as leis; por outro lado, como uma pessoa justa, que deseja ter as graças e as desgraças da fortuna em igual medida. O igual é oposto a ambos, isto é, ao que é excessivo e ao que é deficiente. Disto, Aristóteles conclui que o que é justo é dito de acordo com a lei e a igualdade, e o que é injusto, contrário a lei e à igualdade, na medida em que os objetos são conhecidos pelo hábito”. (p. 282).
} 
distribuição, pela Pólis, de honras, riquezas ou de outras vantagens que são repartidas entre os membros de uma comunidade política. Neste rol, encontram-se responsabilidades, deveres e impostos (BITTAR; ALMEIDA, 2015, p. 133). Anota Aristóteles:

\begin{abstract}
Uma das espécies de justiça em sentido estrito e do que é justo na acepção que lhe corresponde, é a que se manifesta na distribuição de funções elevadas de governo, ou de dinheiro, ou das outras coisas que devem ser divididas entre os cidadãos que compartilham dos benefícios outorgados pela constituição da cidade, pois em tais coisas uma pessoa pode ter participação desigual ou igual à de outra pessoa (ARISTÓTELES, 1996, p. 197).
\end{abstract}

O objeto da justiça distributiva se constitui da distribuição de deveres previstos pelas leis produzidas pelo seu governante. Caracteriza, então, uma relação de subordinação tanto política quanto jurídica entre o governante e seus governados. Consiste, ainda, em uma distribuição realizada de maneira justa, logo, mediante o mérito individual. Não respeitando esta premissa, verifica-se a injustiça sendo o injusto como o desigual, visto o recebimento de benefícios e encargos em quantia menor ou maior ao que lhe é devido. Conforme ensina Aristóteles:

\begin{abstract}
O justo nesta acepção é, portanto o proporcional, e o injusto é o que viola a proporcionalidade. Neste último caso, um quinhão se torna muito grande e outro muito pequeno, como realmente acontece na prática, pois a pessoa que age injustamente fica com um quinhão muito grande do que é bom e a pessoa que é tratada injustamente fica com um quinhão muito pequeno. No caso do mal o inverso é verdadeiro, pois o mal maior, já que o mal menor deve ser escolhido em preferência ao maior, e o que é digno de escolha é um bem, e o que é mais digno de escolha é um bem ainda maior (ARISTÓTELES, 1996, p. 199).
\end{abstract}

Percebe-se que a justiça distributiva é um meio-termo com quatro termos na relação: dois sujeitos comparados entre si e dois objetos. Será justo, portanto, se atingir a finalidade de dar a cada um aquilo que lhe é devido, na medida de seus méritos:

Se as pessoas são iguais, as partes serão iguais, e se as pessoas são desiguais, as partes serão desiguais; o justo consiste em tratar desigualmente fatores desiguais. $\mathrm{O}$ justo sendo o que é proporcionalmente igual, e o injusto o que é contrário à proporção (TRICOT, 1959, p. 127).

Aristóteles define que a relação de igualdade existente entre as coisas também existirá nas pessoas contidas na distribuição. Logo, pessoas desiguais recebem partes desiguais, enquanto que pessoas iguais recebem partes iguais; sendo que a justiça será 
realizada conforme o mérito do recebedor. Será fato gerador de disputas ou queixas - entre os cidadãos - tratar pessoas iguais desigualmente, tratar pessoas desiguais igualmente ou fazer distribuições em desacordo com o seu quinhão merecido.

\subsection{A JUSTIÇA CORRETIVA}

A justiça Corretiva também se apresenta na modalidade de justiça que nasce de acordo com a lei produzida pela própria sociedade política. Difere-se no sentido de que, enquanto a Justiça Distributiva atua na esfera do direito público, a Justiça Corretiva trabalha com o direito privado, relacionada com as transações particulares, ou seja, restabelecendo o equilíbrio rompido entre os particulares: a igualdade aritmética (BITTAR; ALMEIDA, 2015, p. 135), que segundo Aristóteles:

\footnotetext{
É a que desempenha função corretiva nas relações entre as pessoas. Esta última se subdivide em duas: algumas relações são voluntárias e outras são involuntárias; são voluntárias a venda, a compra, o empréstimo a juros, o penhor, o empréstimo sem juros, o depósito e a locação (estas relações são chamadas voluntárias porque sua origem é voluntária); das involuntárias, algumas são sub-reptícias (como o furto, o adultério, o envenenamento, o lenocínio, o desvio de escravos, o assassino traiçoeiro, o falso testemunho), e outras são violentas, como o assalto, a prisão, o homicídio, o roubo, a mutilação, a injúria e o ultraje (ARISTÓTELES, 1996, p. 197).
}

$\mathrm{Na}$ justiça corretiva, como visto, se tem por finalidade alcançar um critério unicamente objetivo e aritmético, não se observando o mérito dos indivíduos. É de se observar que, em princípio, todas as partes envolvidas nas relações perante a justiça corretiva são iguais, visto que esta modalidade de justiça é vinculada ao objeto, à situação da pessoa envolvida e não à pessoa individualmente considerada, como acontece na justiça distributiva.

De tal sorte que, observadas as nuances da situação, o justo corretivo será uma forma de igualdade decorrente das transações particulares, e o inverso será o injusto que está em desigualdade, situação na qual o juiz se esforçará para igualar utilizando uma sanção. A aplicação da justiça corretiva deve estar vinculada ao juiz, mediador de todo o processo, visto que o juiz é a personificação da justiça, como se observa: 
Ir ao juiz é ir à justiça, porque se quer que o juiz seja como se fosse a própria justiça viva [...] é uma pessoa equidistante e, em algumas cidades são chamados de 'mediadores', no pressuposto de que, se as pessoas obtêm o meio-termo, elas obtêm o que é justo (ARISTÓTELES, 1996, p. 200).

É de se observar que a construção da justiça distributiva é função do legislador, enquanto que na justiça corretiva, sua produção é função do juiz. Assim, o juiz procura restabelecer a desigualdade provocada pela perda e procura igualar com o ganho. Ao igualar a perda em relação ao ganho, o juiz aplicou o "justo". Logo, este ato que corrige uma situação de injustiça, que realiza a justiça corretiva, poderá ser chamado de "ato de justiça."

\subsection{JUSTIÇA POLÍTICA E JUSTIÇA DOMÉSTICA}

Observa-se que a justiça política está entranhada no âmbito da sociedade, na sociabilidade em comum das relações dos cidadãos na Pólis. Logo, a justiça política determinará a aplicação da justiça, das regras de convívio em sociedade, organizará um modo de vida comunitária entre indivíduos que partilham um espaço comum, com divisões das atividades, com vistas à liberdade e igualdade entre eles. Será a justiça a organizar um modo de vida que tende à autossuficiência da vida comunitária, vigente entre homens que partilham de um espaço comum (BITTAR; ALMEIDA, 2015, p. 140). Assim, nos ensinamentos de Aristóteles, o justo político:

\footnotetext{
Se apresenta entre as pessoas que vivem juntas com o objetivo de assegurar a autossuficiência do grupo - pessoas livres e proporcionalmente ou aritmeticamente iguais. Logo, entre pessoas que não se enquadram nesta condição não há justiça política, e sim a justiça em um sentido especial e por analogia (ARISTÓTELES, 1996, p. 205).
}

Assim, para a aplicação da justiça política, somente seria direcionada aos membros considerados cidadãos na Pólis, visto o conjunto restrito e excludente de algumas camadas como os estrangeiros, escravos, menores, as mulheres e aqueles que não são livres, sendo que, para estes, a justiça política atingia-os de forma indireta.

A justiça doméstica é tratada nas relações familiares (pais e filhos) e escravistas (senhor e escravo), ou seja, está entranhada no âmbito residencial. Portanto, pode-se dizer que a justiça doméstica tem estas últimas como espécies (justiça para com a mulher; justiça para 
com os filhos; justiça para com os escravos) (BITTAR; ALMEIDA, 2015, p. 142). Do mesmo modo, verifica-se os ensinamentos de Aristóteles sustentando que:

\begin{abstract}
A justiça do senhor para com o escravo e a do pai para com o filho não são iguais à justiça política, embora se the assemelhem; na realidade, não pode haver injustiça no sentido irrestrito em relação a coisas que nos pertencem, mas os escravos de um homem, e seus filhos até uma certa idade em que se tornam independentes, são por assim dizer partes deste homem, e ninguém faz mal a si mesmo (por esta razão uma pessoa não pode ser injusta em relação a si mesma) (ARISTÓTELES, 1996, p. 205).
\end{abstract}

Observa-se que ninguém é capaz de fazer mal a si, portanto, não há de se afirmar que existe justiça ou injustiça nessas situações, pois o pai e senhor possuem poder irrestrito sob seus filhos e seus escravos. Isto significa que a justiça doméstica abrange questões domésticas ligadas às economias da legislação do lar atinentes aos particulares na administração da coisa particular.

\title{
2.5 JUSTIÇA LEGAL E JUSTIÇA NATURAL
}

O que distingue o homem dos outros seres é sua capacidade de pensar e de se orientar por si mesmo. São estas funções que constituem a razão, a qual proporciona ao homem diferenciar o bem do mal. Este caráter racional é próprio da natureza humana, logo, a pessoa recebe este dote ao nascer (SILVA, 2004, p. 49). Assim, observam-se características específicas e naturais entranhadas no caráter da pessoa humana, como a inteligência, o discernimento e a intuição. E isto permite visualizar e diferenciar as variáveis de justiça como visto até aqui.

Aprofundando a teoria sistemática da justiça aristotélica, verifica-se que a justiça legal e a justiça natural são divisões do gênero da justiça política. Sobre a distinção aristotélica entre o justo legal e o justo natural, no sentido de que aquele corresponde às prescrições derivadas do nómos ${ }^{9}$, isto é, das regras vigentes entre os cidadãos políticos, e este, encontra fundamento na própria natureza (BITTAR; ALMEIDA, 2015, p. 144), Aristóteles explica que:

\footnotetext{
${ }^{9}$ A lei, segundo a filosofia grega da Antiguidade, explicada como uma convenção dependente do artifício humano ou, para outras correntes, das leis da natureza, em ruptura com as legitimações jurídicas fundamentadas na religiosidade e na tradição.
} 
A justiça política é em parte natural e em parte legal; são naturais as coisas que em todos os lugares têm a mesma força e não dependem de as aceitarmos ou não, e é legal aquilo que a princípio pode ser determinado indiferentemente de uma maneira ou de outra, mas depois de determinado já não é indiferente (ARISTÓTELES, 1996, p. 206).

A justiça legal corresponde às prescrições vigentes entre os cidadãos. Tais prescrições são feitas pelo legislador, de forma que aquilo que a princípio era indiferente, passa a ser vinculativo para todos os cidadãos. Possui força não natural sendo fundada na convenção, pois a vontade do órgão que emana o ato legislativo é soberana e pressupõe consenso de todos os súditos, uma vez vigente, a lei adquire obrigatoriedade e vincula todos os cidadãos.

Diferentemente da justiça legal, a justiça natural tem sua fundamentação não na vontade humana preceituada, mas na própria natureza, independentemente de qualquer ato de positividade do Legislativo. É o conjunto de todas as regras que encontram aplicação, validade, força e aceitação universais. Dessa maneira, pode-se definir o justo natural como sendo parte do justo político, que encontra respaldo na natureza humana, e não depende do arbítrio volitivo do legislador, sendo, por consequência, de caráter universalista (BITTAR; ALMEIDA, 2015, p. 145). Portanto, a justiça natural tem uma força que rompe com as barreiras políticas, que transcende a vontade humana e é imutável, e tem a mesma forma em todo lugar, como o fogo que queima aqui e na Pérsia (ARISTÓTELES, 1996, p. 206).

\subsection{EQUIDADE}

Nesta visão de justiça, identifica o filósofo que, entre o excesso e a falta de justiça, encontrar-se-á o intermediário, visto que a excelência moral não está nos extremos, logo, o ponto de equilíbrio encontra-se no equidistante e, assim, a equidade constrói a excelência moral, tornando-se o grau mais elevado de justiça.

Observa-se que, para Aristóteles, a equidade compara-se diretamente à justiça. Conclui que são a mesma coisa, embora a equidade seja melhor, pois esta se configura como corretivo da justiça legal. Aduz Aristóteles que "o que cria o problema é o fato de o equitativo ser justo, mas não justo segundo a lei, e sim um corretivo da justiça legal” (ARISTÓTELES, 1996, p. 212). 
Quando observa-se uma disputa ou enfrenta-se o litígio judicial, os envolvidos recorrem ao magistrado, tendo em vista que o juiz é a própria justiça, portanto, como agente equidistante na tríade da lide, encontrar-se-á o meio-termo, exatamente o que é o justo. Logo, o justo é equidistante, já que o juiz o é (ARISTÓTELES, 1992, p. 98). O juiz deve observar sempre as nuances e peculiaridades do caso concreto, avaliando todos os aspectos necessários para a melhor decisão, indagando-se qual ação o próprio legislador tomaria se estivesse presente e o que teria incluído em sua lei se houvesse previsto o caso em questão (ARISTÓTELES, 1996, p. 213).

Assim, a equidade tem a função de corrigir a lei, do caráter geral para o particular, objetivando realizar a justiça. O juízo de equidade corresponde à justiça no âmbito individual e efetiva a aplicação da justiça, em relação àquela especificidade não incluída na lei. Serão regras particulares com aplicabilidade às especificidades de cada caso, com o objetivo de suprir a omissão legal não observada pelo legislador. Nesta equidade, Aristóteles ilustra como exemplo a régua de Lesbos, como se observa:

Com efeito, quando uma situação é indefinida a regra também tem de ser indefinida, como acontece com a régua de chumbo usada pelos construtores em Lesbos; a régua se adapta à forma da pedra e não é rígida, e o decreto se adapta aos fatos de maneira idêntica (ARISTÓTELES, 1996, p. 213).

Por fim, a equidade tratará da adequação da lei ao caso concreto, observando as peculiaridades do caso concreto em relação ao caráter abstrato e genérico da lei, sendo o magistrado responsável em trazer ponderação proporcional ao julgamento da disputa.

\section{O JUIZ DAS GARANTIAS NA JUSTIÇA ARISTOTÉLICA}

Verificou-se as modalidades de justiça segundo as constatações de Aristóteles, dentro do campo da ética, passando sua observação para o campo da ciência prática. É razoável apontar que se trata de tema complexo, exaustivamente teorizado e melhorado por filósofos posteriores, adentrando até os dias atuais. São Tomás de Aquino, por exemplo, realiza a intersecção das Sagradas Escrituras em conjunto ao pensamento aristotélico, por meio de um enfoque teológico aos ensinamentos aristotélicos "[...] utiliza la teoria aristotélica em la perspectiva teológica" (AQUINO, 1995, p. 457). 
No estudo minucioso sobre as nuances da teoria sistemática da Justiça catalogadas por Aristóteles, mais do que defini-las, deve-se compreendê-las nas peculiaridades jurídicas e como se comportam no sistema jurídico brasileiro, relacionando-as aos fatos jurídicos contemporâneos vistos (NALINI; LEVY, 2015, p. A3), por exemplo, o juiz das garantias.

Não se trata de tema novo, haja vista suas discussões para o novo Código de Processo Penal proposto pelo Senado, em tramitação desde 2009. A sanção da lei 13.964/2019 pelo presidente Jair Bolsonaro no dia 24 de dezembro de 2019 introduziu o juiz das garantias, dentre outras mudanças no Código Penal Brasileiro. É bem verdade que a exigência da imparcialidade do juiz não deveria ser questionada nas discussões acadêmicas e, tampouco, existir dificuldades práticas (PRADO, 2016, p. 2016).

A criação do juiz das garantias é um grande avanço quando observada pelo prisma da justiça corretiva de Aristóteles, pois o juiz zelará ainda mais pela imparcialidade, garantindo total controle da legalidade da investigação criminal. Pode também se justificar por meio da justiça equitativa, no objetivo primário de realizar justiça. De tal sorte, é possível correlacionar o instituto do juiz das garantias mediante os preceitos de justiça observados nos estudos de Aristóteles, pois a medida busca ampliar cada vez mais a imparcialidade do Judiciário.

\subsection{DÚBIO CREPÚSCULO DA IMPARCIALIDADE}

A reportagem do The Intercept Brasil ${ }^{10}$ inicia uma série de matérias que mostram uma estreita relação entre o ex-juiz Federal Sérgio Moro e os procuradores da Operação Lava Jato, em especial, Deltan Dallagnol. Questões como o tempo entre uma fase e outra da operação e quais provas seriam mais eficazes para pedir a condenação de Lula no caso do

\footnotetext{
$10 \mathrm{O}$ "The Intercept Brasil" é uma premiada agência de notícias dedicada à responsabilização dos poderosos por meio de um jornalismo destemido e combativo. Suas investigações aprofundadas e suas análises implacáveis se concentram em política, corrupção, meio ambiente, segurança pública, tecnologia, mídia e muito mais. O The Intercept dá aos seus jornalistas a liberdade editorial e o suporte legal de que precisam para expor a corrupção e a injustiça onde quer que as encontrem (definição do próprio site).
} 
tríplex do Guarujá, foram abordadas pelo ex-juiz Sérgio Moro e Deltan Dallagnol, segundo as reportagens.

Ao longo dos meses, viu-se discussões sobre a veracidade dos fatos, de um lado, o Ministério Público e o ex-juiz alegando que foram vítimas de um hacker em seus aparelhos celulares que difundiu informações não verídicas. De outro lado, o site The Intercept Brasil alegando sistematicamente que houve quebra do sistema acusatório penal, uma vez que as mensagens sugerem colaboração real entre o Magistrado e membros do Ministério Público na força tarefa. O que se tem de fato, neste momento, é a incerteza sobre uma parcialidade dos agentes públicos no processo acusatório penal da Operação Lava Jato e a troca de acusações em ambos os lados.

Entretanto, aprovado o "Pacote Anticrime" pelo Congresso Nacional, fora incluído o juiz das garantias justamente com a intenção de garantir imparcialidade no processo acusatório. Os críticos mais contumazes da Lava Jato alegam que se trata de grande avanço civilizatório, pois garantem a imparcialidade no processo nos mesmos moldes de países como os Estados Unidos e a Espanha, seguidos pelo México, Chile e Bolívia, que implantaram o juiz das garantias objetivando o garantismo (FERRAJOLI, 2006, p. 25) por meio de técnicas previstas no ordenamento para possibilitar a máxima efetividade de todas as normas em plena coerência com os princípios constitucionais.

\subsection{APLICABILIDADE DO JUIZ DAS GARANTIAS}

O atual Código de Processo Penal determina que o mesmo juiz acompanhe a fase de investigação, faça a produção de provas e, por fim, aplique a sentença. Seguindo a justiça corretiva de Aristóteles, o juiz das garantias poderá garantir a imparcialidade, pois será equidistante de todo o processo acusatório. Logo, para que a imparcialidade seja preservada, é necessário - além da separação inicial das funções de acusar e julgar -, um afastamento do juiz da atividade investigatória/instrutória (LOPES JUNIOR, 2018).

Nesta mudança, o juiz das garantias será o responsável do processo até o momento da denúncia, realizada pelo Ministério Público, ou a queixa-crime nas ações penais privadas. Após a aceitação, é evocado um segundo juiz denominado juiz de instrução, responsável, por exemplo, em ouvir testemunhas e, por fim, realizar a sentença. Todo o processo de investigação será conduzido pelo juiz das garantias, como decretar ou prorrogar a prisão 
preventiva, interceptação telefônica, obtenção de provas, busca e apreensão, dentre outras ações.

É de extrema relevância observar que existem dois tipos de sistema penal, a saber: o inquisitório - no qual o magistrado será o responsável em levar provas ao processo, e o acusatório, sendo as partes responsáveis pelas provas no processo. É clara a observância da Constituição Federal de 1988 ao modelo acusatório no tocante ao artigo 129, I, que assevera como função privativa do Ministério Público a promoção da ação penal (BRASIL, 2020a). Portanto, é notória a clareza o prestígio da lei 13.964/2019 para a Constituição Federal.

Com a sanção presidencial, coube ao Conselho Nacional de Justiça (CNJ) iniciar os trabalhos para realizar a implementação do juiz das garantias no ordenamento jurídico penal. A questão prática passa por um grupo de trabalho instituído pela Portaria CNJ 214/2019, no qual será realizado estudo relativo aos efeitos da aplicação do juiz das garantias nos Tribunais.

O prazo exíguo para implementação e, ao menos, $19 \%$ das varas da justiça estadual possuírem um único juiz (TUROLLO JR, 2020), poderão ser impeditivos para a implementação imediata. Portanto, não se estranha um novo parecer do presidente do CNJ e do Supremo Tribunal Federal (STF) em estabelecer prazo de 180 dias para aplicação da lei na intenção de realizar a transição para o novo modelo, além de prorrogar o prazo para o grupo de trabalho concluir seus estudos (BRASIL, 2020b). Com um prazo maior, será possível um relativo planejamento, priorizando a qualidade dos estudos realizados pelo grupo de trabalho do CNJ.

\section{CONCLUSÃO}

O modelo de filosofia, como se conhece, é oriundo dos filósofos Sócrates, Platão e Aristóteles, precursores da implementação da razão para a compreensão do universo, da política, da vida humana e de valores como felicidade e virtude. Aristóteles aprofundou seus estudos com base nos ensinamentos de seu mestre Platão, passando por várias áreas como a Lógica, a Física, Cosmologia e a Antropologia, também a Filosofia Teorética e a Metafísica. Sua obra, Ética a Nicômaco - que permeou o presente estudo, é o escrito mais maduro, pois emprega seu próprio sistema filosófico - agora bem distante de seu mestre - compondo o corpo denominado ética aristotélica por meio das obras Ética à Nicômaco, Ética à Eudemo e A Grande Ética. 
A obra Ética à Nicômaco aprofunda, com notória maestria, o conceito de Justiça, classificando-a como a busca do equilíbrio, do proporcional, por meio da contraprestação justa ao agravo que a gerou. Atribui, ainda, que a justiça nada mais é do que a excelência pela virtude por meio da total virtude moral. Logo, somente por intermédio da educação totalmente direcionada para a prática da ética será possível conceber um homem justo, sendo este probo à lei e aos seus consortes que, por sua vez, o inverso - o homem injusto - é o homem sem lei, o que não respeita os consortes. Pode-se afirmar que a virtude é o meio-termo entre os extremos, sendo um denominado como excesso e o outro por falta.

O conceito de justiça na visão aristotélica, assim como a virtude, está vinculado diretamente na disposição do caráter humano classificando a justiça como sendo a virtude total, logo, completa, pois o homem justo exercerá a sua virtude em seu favor e também em relação ao próximo, e a virtude ligada à moral humana sendo intrínseca ao indivíduo. Devido à natureza do homem no gregarismo, é natural a propensão à vida social e, ainda, justiça e virtude se igualam na vida em sociedade. Pois bem, classifica-se o homem como virtuoso quando segue seus valores de forma incorruptível e no caráter irrefutável, mesmo diante da ausência ou conhecimento da lei.

Contribui o filósofo, ainda, para o entendimento das variáveis da justiça, as explicações e delineações de termos complexos e sua aplicabilidade na Pólis. Tendo como pano de fundo a justiça corretiva e equidade como pilares fundamentais para a implantação do juiz das garantias, pode-se incutir ao operador do Direito a validade do instituto como normal ideal para a validação da imparcialidade no sistema processual penal. É inquestionável, sob o prisma da justiça de Aristóteles, o avanço do processo penal por meio de um instituto moderno que fortalece a imparcialidade do magistrado, pavimenta substancialmente o princípio do acusatório, combate à impunidade e, por fim, concretiza essencialmente a persecução penal.

Subdividir o processo em duas etapas, na primeira, o juiz tomará as medidas necessárias para a investigação criminal e avaliação das provas, e na segunda, na aplicação da sentença, é de muito bom senso, visto a imparcialidade e a equidade como pilares fundamentais do processo penal. O processo de implantação estendido para 180 dias é de bom tom diante de problemáticas inerentes aos Tribunais, como o número insuficiente de juízes em determinadas comarcas, processos não digitais, processos com ritos próprios e demais variáveis específicas. Portanto, é notória a necessidade do juiz das garantias, no intuito de se 
ter uma justiça imparcial, mas será necessário aguardar sua implementação de forma ampla nos Tribunais brasileiros.

\section{REFERÊNCIAS}

AQUINO, São Tomás de. Suma de teología. Edição dirigida por los Regentes de Estudios de las Provincias Dominicanas em España. Madrid: Biblioteca de Autores Cristianos. 1995

AQUINO, São Tomás de. Commentary on Aristotle's Nicomachean Ethics. Transl. by C. I. Litzinger. Foreword by R. McInerny. revised edition. Aristotelian Commentary Series. Notre Dame, Dumb Ox Books. 1993.

ARISTÓTELES. Ética à Nicômaco. São Paulo: Nova Cultural, 1996.

ARISTÓTELES. Ética a Nicômaco. Tradução de Mário da Gama Kury. 3 ed. Brasília: Editora Universidade de Brasília, 1992.

BITTAR, Eduardo C. B.; ALMEIDA, Guilherme Assis de. Curso de Filosofia do Direito. 11 ed. São Paulo: Atlas, 2015.

BRASIL. STF. Ação direta de inconstitucionalidade nº 6298 MC/DF - Distrito Federal. Relator: Ministro Luiz Fux. STF, 2020a. Disponível em:

http://www.stf.jus.br/arquivo/cms/noticiaNoticiaStf/anexo/Juizdasgarantias.pdf. Acesso em: 15 jan. 2020.

BRASIL. CNJ. Decisão estende prazo para aplicação da lei que cria o juiz das garantias. CNJ, 2020b. Disponível em: https://www.cnj.jus.br/decisao-estende-prazo-para-aplicacao-da-leique-cria-o-juiz-das-garantias/. Acesso em: 15 jan. 2020.

CHALITA, Gabriel. Aristóteles e o direito. In: CAMPILONGO, Celso Fernandes; GONZAGA, Alvaro de Azevedo; FREIRE, André Luiz (coords.). Enciclopédia jurídica da PUC-SP. Tomo: Teoria Geral e Filosofia do Direito. São Paulo: Pontifícia Universidade Católica de São Paulo, 2017. Disponível em:

https://enciclopediajuridica.pucsp.br/verbete/11/edicao-1/aristoteles-e-o-direito. Acesso em: 15 dez. 2020.

D’URSO, Luiz Flávio Borges. Juiz de garantias - são positivas as mudanças propostas pelo novo Código de Processo Penal? Folha de São Paulo, 2010. Disponível em: http://www1.folha.uol.com.br/fsp/opiniao/fz2003201008.htm. Acesso em: 15 dez. 2020.

FERRAJOLI, Luigi. Derecho como sistema de garantias. 5 ed. Madri: Editora Trotta, 2006.

TUROLLO JR, Reynaldo. Toffoli nega custos extras e banca juiz das garantias com quadro atual do Judiciário. Folha de São Paulo, 2020. Disponível em: 
https://www1.folha.uol.com.br/poder/2020/01/toffoli-nega-custos-extras-e-banca-juiz-dasgarantias-com-quadro-atual-do-judiciario.shtml. Acesso em: 05 jan. 2020.

LOPES JUNIOR, Aury. A tridimensionalidade da crise do processo penal brasileiro: crise existencial, identitária da jurisdição e de (in)eficácia do regime de liberdade individual.

Revista Brasileira de Ciências Criminais, v. 143. São Paulo: Revista dos Tribunais, maio, 2018.

MORRIS, Clarence. Grandes filósofos do direito. São Paulo: Martins Fontes, 2002.

NALINI, José Renato; LEVY, Wilson. Novos amigos para a Justiça. Folha de São Paulo, 2015. Disponível em: https://www1.folha.uol.com.br/opiniao/2015/04/1619387-jose-renatonalini-e-wilson-levy-novos-amigos-para-a-justica.shtml. Acesso em: 12 jun. 2020.

NEVES, Orlando. Dicionário da origem das palavras. Portugal: Oficina do Livro, 2012. PRADO, Geraldo. Entre a imparcialidade e os poderes de instrução no caso Lava Jato: Para além da iniciativa probatória do juiz. Revista Brasileira de Ciências Criminais, v. 122. São Paulo: Revista dos Tribunais, set./out., 2016.

SILVA, Moacyr Motta da. Direito, justiça, virtude moral \& razão. Curitiba: Juruá, 2004.

STANFORD ENCYCLOPEDIA OF PHILOSOPHY. Aristotle. Stanford Encyclopedia of Philosophy, 2008. Disponível em: https://plato.stanford.edu/entries/aristotle/\#AriLif. Acesso em: 15 dez. 2020.

TRICOT, J. La Politique. Nouvelle traduction avec introduction notes et index par J. Tricot. Paris: Vrin, 1959.

WATANABE, Ligia Araújo. Platão por mitos e hipóteses. 2 ed. São Paulo: Moderna, 2006. 